\title{
The Role of Serotonin in Antipsychotic Drug Action
}

\author{
Herbert Y. Meltzer, M.D.
}

Recent interest in the role of serotonin (5-HT) in antipsychotic drug action is based mainly upon the fact that antipsychotic drugs such as clozapine, olanzapine, quetiapine, risperidone, sertindole, and ziprasidone are potent $5-\mathrm{HT}_{2 a}$ receptor antagonists and relatively weaker dopamine $\mathrm{D}_{2}$ antagonists. These agents share in common low extrapyramidal side effects at clinically effective doses and possibly greater efficacy to reduce negative symptoms. As a group, they also have a superior effect on cognitive function and greater ability to treat mood symptoms in both patients with schizophrenia or affective disorders than typical antipsychotic drugs. The atypical antipsychotic agents vary in their affinities for other types of 5-HT as well as dopamine, muscarinic, adrenergic, and histaminic receptors, some, or all of which, may contribute to their differences in efficacy and side effect profile. Of the other 5-HT receptors which these drugs directly, the $5-\mathrm{HT}_{1 a}$ and $5-H T_{2 c}$ receptors are the strongest candidates for contributing to their antipsychotic action and low EPS profile. The 5- $\mathrm{HT}_{6}$ and $5-\mathrm{HT}_{7}$ receptors may also be of some importance. Stimulation of the $5-H T_{1 a}$ receptor appears to produce many of the same effects as antagonism of the $5-\mathrm{HT}_{2 a}$ receptor while antagonism of the $5-\mathrm{HT}_{2 c}$ receptor appears to diminish some of the actions of 5-HT $\mathrm{H}_{2 a}$ receptor antagonism. Future antipsychotic drug development can include targeting multiple serotonin receptor subtypes.

[Neuropsychopharmacology 21:106S-115S, 1999]

(C) 1999 American College of Neuropsychopharmacology. Published by Elsevier Science Inc.
Recent interest in the role of serotonin (5-HT) in the mechanism of action of antipsychotic drugs is in large part the result of the discovery of the efficacy of clozapine in treating the delusions, hallucinations, and disorganization of schizophrenic patients who failed to respond to classical neuroleptic drugs (Kane et al. 1988; Meltzer 1992). It has also been demonstrated that clozapine can improve the negative symptoms of schizophrenia, i.e., affective flattening, anergia, anhedonia, and avolition (Meltzer et al. 1996). Clozapine was, earlier, shown to cause fewer extrapyramidal side effects

From the Department of Psychiatry, Vanderbilt University School of Medicine, Nashville, TN.

Address reprint requests to: Dr. H.Y. Meltzer, Vanderbilt University, Psychiatric Hospital, VUI Psychopharmacology/525, Room 305, 1601 23rd Avenue South, Nashville, TN 37232.

Received November 10, 1998; revised March 15, 1999; accepted April 2, 1999.
(EPS) than typical antipsychotic drugs; there have been no reported cases of tardive dyskinesia with clozapine, and it is tolerable to patients with Parkinson's disease and even able to improve some types of motor dysfunction in patients who develop dopamine (DA) agonistinduced psychosis (see Meltzer and Nash 1991; Meltzer et al. 1995 for refs). Clozapine has also been found not to cause elevations of serum prolactin levels (Meltzer 1979). Recently, clozapine has been shown to have other clinical advantages over typical neuroleptic drugs, most notably the ability to improve some aspects of the cognitive dysfunction of schizophrenia, such as attention, verbal fluency (semantic memory), recall memory, and some measures of executive function, e.g., maze and performance, thought it does not improve working memory (Meltzer and McGurk in press). There is extensive evidence that clozapine is able to decrease the risk of suicide in schizophrenia (Meltzer and Okayli 1995). It has also been found effective as an antimanic agent and 
a mood stabilizer in treatment-resistant mood disorders (Calabrese et al. 1996). Suicide, mania, depression, and mood stabilization have been related to abnormalities in serotonergic availability and receptor responsivity (Maes and Meltzer 1995). Determining the biological basis for these advantages of clozapine, many of which may involve effects on 5-HT, is of great theoretical and clinical importance.

Because clozapine produces agranulocytosis, developing other antipsychotic drugs with similar benefits but without this side effect has been a major research goal since 1988. This effort has produced risperidone, olanzapine, quetiapine, ziprasidone, and sertindole which have been approved for use in the treatment of schizophrenia in various countries as well as other putative antipsychotic agents in development, e.g., M100907. However, there appear to be differences between these agents in efficacy and in at least some side effects. This review considers what is known about the role of 5-HT in the efficacy for positive and negative symptoms, neuroleptic refractory positive symptoms, and extrapyramidal side effects of the novel antipsychotic agents, and looks at possible strategies for developing other antipsychotic agents which depend upon serotonergic function in ways that differ from clozapine. Because of space limitation, this review cannot cover all of the topics in depth; therefore, other reviews of these topics also should be consulted (Meltzer and Nash 1991; Schmidt et al. 1995; Kapur and Remington 1996; Meltzer and Fatemi 1996; Abi-Dargham et al. 1997; Kinon and Lieberman 1996; Arndt and Skarsfeldt 1998).

\section{SEROTONIN RECEPTORS INVOLVED IN ANTIPSYCHOTIC DRUG ACTION}

The major 5-HT receptors that are implicated in the action of clozapine and other recently introduced antipsychotic agents, or are of potential value for developing more effective or better tolerated antipsychotic agents include the following: 5- $\mathrm{HT}_{1 \mathrm{a}}, 5-\mathrm{HT}_{2 \mathrm{a}}, 5-\mathrm{HT}_{2 \mathrm{c}}, 5-\mathrm{HT}_{3}$, $5-\mathrm{HT}_{6}$, and $5-\mathrm{HT}_{7}$ receptors (Meltzer and Nash 1991). These are also of potential value for developing more effective or better tolerated antipsychotic agents. It has been hypothesized that a relatively high $5-\mathrm{HT}_{2 \mathrm{a}}$ receptor affinity compared to the $\mathrm{D}_{2}$ receptor is the basis for the difference between 'atypical' and 'typical' antipsychotic agents (with atypical antipsychotic defined as an agent causing low EPS at doses with demonstrated or putative antipsychotic activity). This hypothesis contributed to the development of the newer antipsychotic agents listed above, all of which are consistent with the hypothesis of high affinity for $5-\mathrm{HT}_{2 \mathrm{a}}$ and low affinity for $D_{2}$ receptors (Schotte et al. 1996). While some of the atypical antipsychotic drugs also have affinities for
$5-\mathrm{HT}_{2 \mathrm{c}}, 5-\mathrm{HT}_{6}$, or $5-\mathrm{HT}_{7}$ receptors that are in the same range as $5-\mathrm{HT}_{2 \mathrm{a}}$ receptors, this is not a common characteristic of these agents and, thus, it is not likely that an affinity for $5-\mathrm{HT}_{2 c}, 5-\mathrm{HT}_{6}$, or $5-\mathrm{HT}_{7}$ receptors are primary factors contributing to the low EPS profile of this class of agents (Roth et al. 1994; Meltzer and Fatemi 1996; Schotte et al. 1996). However, this does not rule out the possibility that the low EPS effects of specific drugs or other actions, depend in part on their affinity for one or more of these 5-HT receptors, including the $5-\mathrm{HT}_{2 \mathrm{c}}$ and 5- $\mathrm{HT}_{7}$ receptors (Meltzer et al. 1996). 5- $\mathrm{HT}_{1 \mathrm{a}}$ receptor agonism has been suggested to contribute to an atypical antipsychotic drug profile (Protais et al. 1994). Furthermore, there is extensive evidence of interactions among $5-\mathrm{HT}_{2 \mathrm{a}}, 5-\mathrm{HT}_{2 \mathrm{c}}$, and $5-\mathrm{HT}_{1 \mathrm{a}}$ receptors (Kapur and Remington 1996; Meltzer et al. 1996b). Because of space limitations, this article will focus on these three 5-HT receptors and only briefly consider the others.

\section{NOVEL ANTIPSYCHOTICS AND THE 5-HT ${ }_{2 \mathrm{~A}}$ RECEPTOR ANTIPSYCHOTIC ACTION}

5- $\mathrm{HT}_{2 \mathrm{a}}$ receptors have been implicated in the genesis of, as well as the treatment of, psychosis, negative symptoms, mood disturbance, and EPS. The hallucinogenic effect of indole hallucinogens has been related to stimulation of 5- $\mathrm{HT}_{2 \mathrm{a}}$ rather than $5-\mathrm{HT}_{2 \mathrm{c}}$ receptors (Fiorella et al. 1995). Numerous studies have demonstrated decreased densities of $5-\mathrm{HT}_{2 \mathrm{a}}$ receptors in various cortical regions of patients with schizophrenia. This does not appear to be secondary to antipsychotic drug-induced down regulation of the density of these receptors (Meltzer et al. 1996b). The antipsychotic effect of clozapine is attributed, in part, to its ability to block excessive $5-\mathrm{HT}_{2 \mathrm{a}}$ receptor stimulation (Meltzer et al. 1989). This conclusion is supported by the high occupancy of 5- $\mathrm{HT}_{2 \mathrm{a}}$ receptors produced by clozapine at clinically effective doses and its low occupancy of $\mathrm{D}_{2}$ receptors (in the 30$50 \%$ range as measured with the $\left[{ }^{3} \mathrm{H}\right]$ raclopride significantly below the 80 to $100 \%$ occupancy produced by typical neuroleptic drugs) (Kapur and Remington 1996). The occupancy of 5- $\mathrm{HT}_{2 \mathrm{a}}$ and $\mathrm{D}_{2}$ receptors has also been studied with other novel antipsychotic drugs, such as risperidone, olanzapine, sertindole, and quetiapine with results similar to those of clozapine; all are more potent $5-\mathrm{HT}_{2 \mathrm{a}}$ and $\mathrm{D}_{2}$ antagonists at appropriate doses, but produce higher $\mathrm{D}_{2}$ occupancy than clozapine. Some of these (e.g., risperidone) agents, produce high $\mathrm{D}_{2}$ occupancy at high doses (Kapur and Remington 1996). Pilowsky et al. (1997a) have observed high occupancy of extrastriatal D2 receptors in clozapine treated patients with schizophrenia in a SPECT study. These findings, if verified, could indicate that the low estimates of $\mathrm{D}_{2}$ receptor occupancy in the basal ganglia by some atypical antipsychotic drugs in some studies are mis- 
leading with regard to the importance of dopamine receptor blockade for their antipsychotic, and perhaps other actions, e.g., cognition and negative symptoms.

To test the contribution of 5- $\mathrm{HT}_{2 \mathrm{a}}$ receptor antagonism to antipsychotic drug action, clinical trials of ritanserin, a potent $5-\mathrm{HT}_{2 \mathrm{a}}$ and $5-\mathrm{HT}_{2 \mathrm{c}}$ antagonist, have been conducted. Although the data suggest little or no beneficial effect (see Martin et al. 1997 for refs), this may be due to two factors: a) $5-\mathrm{HT}_{2 \mathrm{c}}$ receptor antagonism opposes the beneficial effects of $5-\mathrm{HT}_{2 \mathrm{a}}$ receptor blockade (see below); and b) too high a dose of neuroleptic (Meltzer and Fatemi 1996). The bell-shaped dose response curve of risperidone, with higher doses being less effective than lower doses (Marder and Meibach 1994), suggests that excessive $D_{2}$ receptor antagonism may reduce the beneficial effects of 5- $\mathrm{HT}_{2 \mathrm{a}}$ receptor blockade (Meltzer and Fatemi 1996). However, other explanations of this finding are also possible. Trials with fixed, low doses of neuroleptic and specific potent $5-\mathrm{HT}_{2 \mathrm{a}}$ antagonists are needed. Amperozide is a relatively selective $5-\mathrm{HT}_{2 \mathrm{a}}$ antagonist which was shown in several studies to have antipsychotic efficacy but again no definite conclusion as to efficacy is possible (Meltzer and Nash 1991). The highly selective $5-\mathrm{HT}_{2 \mathrm{a}}$ antagonist, M100907, formerly MDL 100907, has been found in a controlled study to have some efficacy for treating positive and negative symptoms in hospitalized schizophrenic patients (Shipley 1998).

Large scale studies are currently underway to more definitively test its efficacy. I hypothesize that this compound will be effective in some patients with schizophrenia, but that there will be a need for low doses of $D_{2}$ receptor antagonists in patients who may have relatively excessive dopaminergic activity. This may be those patients with acute, florid psychoses. Other $5-\mathrm{HT}_{2 \mathrm{a}}$ selective agents such as SR 46349B (Rinaldi-Carmona et al. 1992) are currently being tested. It should soon be apparent whether $5-\mathrm{HT}_{2 \mathrm{a}}$ receptor blockade alone can achieve a sustained antipsychotic action. The potent $\mathrm{D}_{4} / 5-\mathrm{HT}_{2 \mathrm{a}}$ receptor antagonist fananserin has been found ineffective in acutely psychotic patients with schizophrenia (Truffinet et al. in press), perhaps because $\mathrm{D}_{4}$ receptor antagonism has a propsychotic effect, not the reverse. Additional evidence supporting the role of $5-\mathrm{HT}_{2 \mathrm{a}}$ receptor blockade in the action of clozapine and possibly other drugs with potent $5-\mathrm{HT}_{2 \mathrm{a}}$ affinities is available from the several reports that the His452Tyr allele of the $5-\mathrm{HT}_{2 \mathrm{a}}$ receptor, which is present in $10-12 \%$ of the population, is associated with a higher frequency of poor response to clozapine (Masellis et al. 1998). Thus, taken together, the evidence from clinical trial data suggests that $5-\mathrm{HT}_{2 \mathrm{a}}$ receptor blockade may contribute to antipsychotic drug action.

Basic research is also supportive of the relevance of $5-\mathrm{HT}_{2 \mathrm{a}}$ receptor blockade to antipsychotic drug action. M100907 or other selective 5- $\mathrm{HT}_{2 \mathrm{a}}$ receptor antagonists, either alone or in combination with selective antagonists of other receptors, have been found to be effective in various animal models of psychosis. These include: 1) blockade of amphetamine-induced locomotor activity and the slowing of ventral tegmental area (A10) dopaminergic neurons (Schmidt et al. 1995); 2) blockade of phencyclidine (PCP)- and dizocilpin (MK-801)-induced locomotor activity (Gleason and Shannon 1997; Martin et al. 1997); 3) blockade of MK-801-induced prepulse inhibition (Varty and Higgins 1995); and 4) antipsychotic- like activity in the paw test.

Increased dopaminergic activity in the nucleus accumbens, other mesolimbic and possibly cortical regions may contribute to positive symptoms, including formal thought disorder. We have previously reported that the 5- $\mathrm{HT}_{2 \mathrm{a} / 2 \mathrm{c}}$ agonist DOI (1-(2,5-dimethoxy-4iodophenyl)-2-aminopropane) which itself had no effect on basal DA release, potentiated amphetamine-induced DA release and attenuated the ability of apomorphine, a direct acting $\mathrm{D}_{1 / 2 / 3}$ agonist, to decrease DA release in the striatum (Ichikawa and Meltzer 1995). We have proposed that short-lasting desensitization of $\mathrm{D}_{2}$ autoreceptors can develop following stimulation of $5-\mathrm{HT}_{2 \mathrm{a}}$ receptors. This desensitization may increase DA synthesis via disinhibition of tyrosine hydroxylase, leading to an additional increase in the size of the DA pool at which amphetamine may act. We have found a similar effect in the nucleus accumbens and prefrontal cortex (Ichikawa and Meltzer 1995). This effect was completely reversed by M100907, which alone had no effect on basal and amphetamine-induced DA release in the nucleus accumbens and medial prefrontal cortex. These results suggest that stimulated DA release, e.g., with stress, may be increased in the forebrain terminal regions secondary to enhanced stimulation of $5-\mathrm{HT}_{2 \mathrm{a}}$ receptors. Agents that block the effect of excessive, but not basal $5-\mathrm{HT}_{2 \mathrm{a}}$ receptor stimulation may be most useful clinically. Schmidt et al. (1995) reported that M100907 increased DA release in the prefrontal cortex and attenuate the amphetamine analog MDMA - induced increase in striatal DA release. Taken together, these data suggest that $5-\mathrm{HT}_{2 \mathrm{a}}$ antagonism by itself may have antipsychotic action when dopaminergic activity is slightly to moderately increased, but as mentioned above some $\mathrm{D}_{2}$ receptor blockade may also be needed when DA efflux is very high. More studies are needed to define the ability of $5-\mathrm{HT}_{2 \mathrm{a}}$ receptor antagonists to potentiate the action of low doses of $\mathrm{D}_{2}$ receptor blockers in animal models as well as in humans.

Recently, Jakab and Goldman-Rakic (1998) have proposed that the $5-\mathrm{HT}_{2 \mathrm{a}}$ receptors on cortical pyramidal neurons may play a crucial role in psychosis by virtue of their ability to modulate intracortical and corticalsubcortical glutamatergic neurotransmission. This could contribute to the ability of 5- $\mathrm{HT}_{2 \mathrm{a}}$ antagonists to attenuate some of the behavioral effects of PCP and ketamine. 
On the other hand, activation of early intermediate genes such as c-fos in the frontal cortex by clozapine and other novel antipsychotic agents (Robertson et al. 1994), does not appear to be related to blockade of $5-\mathrm{HT}_{2 \mathrm{a}}$ receptors since ritanserin alone, or the combination of ritanserin and sulpiride, a $\mathrm{D}_{2} / \mathrm{D}_{3}$ antagonist, did not mimic the effects of clozapine to activate Fos expression in the prefrontal cortex (Deutch and Duman 1996). As in many studies which employ this combination strategy, the dose of the $D_{2} / D_{3}$ antagonist may have been excessive. It would be of considerable interest to study the effect of a series of doses of M100907, a selective 5-HT2a receptor antagonist, and relatively low doses of a selective $D_{2} / D_{3}$ antagonist, on rat brain c-fos expression. On the other hand, lesioning the serotonergic afferents to the medial prefrontal cortex also did not affect the ability of clozapine to activate Fos protein in the frontal cortex (Guo et al. 1995). It is important to note that the $5-\mathrm{HT}_{2 \mathrm{a} / 2 \mathrm{c}}$ agonist (DOI), increased the expression of fos protein in frontal and other cortical and limbic areas (Leslie et al. 1993), most likely through a $5-\mathrm{HT}_{2 \mathrm{a}}$ mechanism. Thus, it seems unlikely that $5-\mathrm{HT}_{2 \mathrm{a}}$ receptor antagonism is involved in the ability of the atypical antipsychotic drugs to stimulate fos expression in the prefrontal cortex. Recent studies have suggested that $\mathrm{D}_{3}$ receptor stimulation may account for this effect (Guo et al. 1995). While the activation of c-fos in the frontal cortex seems not to be related to $5-\mathrm{HT}_{2 \mathrm{a}}$ receptor antagonism, it nevertheless seems likely that the latter contributes to the antipsychotic action of the atypical antipsychotic drugs when associated with low $\mathrm{D}_{2}$ receptor occupancy, and not accompanied by effects such as $5-\mathrm{HT}_{2 \mathrm{c}}$ or possibly $\mathrm{D}_{4}$ receptor antagonism which may negate some of the beneficial effects of $5-\mathrm{HT}_{2 \mathrm{a}}$ receptor antagonism. It should be kept in mind that the clinical significance of activation of c-fos expression in the frontal cortex is still quite speculative.

\section{TREATMENT RESISTANT SCHIZOPHRENIA AND 5-HT ${ }_{2 \mathrm{~A}}$ RECEPTOR BLOCKADE}

Clinical studies have suggested that clozapine is much more effective than the other novel antipsychotic drugs in treatment resistant schizophrenia (Meltzer 1997). One recent study found no effect of high doses of olanzapine in treatment resistant schizophrenia (Conley et al. 1998a), though there is limited published evidence that risperidone is effective in this patient group (Bondolfi et al. 1998). However, there is extensive clinical experience that some patients who are refractory to typical neuroleptic drugs, and even clozapine, may respond to olanzapine or risperidone (Conley et al. 1998b; Ganguli and Brar 1998; Mountjoy et al. 1998). Head to head comparisons with clozapine and cross over studies are needed to determine the relative efficacy of the atypical agents in this regard. It should be noted that there are varying degrees of neuroleptic resistance and that studies which are designed to determine whether other antipsychotic drugs are as effective as clozapine for treatment resistant schizophrenia should use rigorous criteria for neuroleptic resistance. The relatively modest effects of drugs such as olanzapine, quetiapine and risperidone in treatment resistant schizophrenia suggests that $5-\mathrm{HT}_{2 \mathrm{a}}$ receptor blockade, even when accompanied by $\mathrm{D}_{2}$ receptor blockade, is only one facet of the explanation of the efficacy of clozapine in neuroleptic-resistant schizophrenic patients. Effects on other 5-HT receptors as well as cholinergic, adrenergic, and dopaminergic mechanisms may be responsible for the greater efficacy of clozapine in this group of patients. Heterogeneity in the basis for neuroleptic resistance is suggested by the variability in response to the atypical antipsychotic drugs. We reported preliminary data that the addition of cyproheptadine, an antagonist of multiple serotonin receptors, to typical neuroleptic drugs appeared to be effective in augmenting the response to the latter in an open study of patients who had become refractory to typical neuroleptic drugs during the course of treatment with clozapine (Meltzer et al. 1996a).

\section{NEGATIVE SYMPTOMS AND 5-HT ${ }_{2 \mathrm{~A}}$ RECEPTOR BLOCKADE}

In contrast to the possibly unique effectiveness of clozapine in diminishing positive symptoms in treatment resistant schizophrenic patients, the atypical antipsychotic drugs (with the possible exception of quetiapine) and some $5-\mathrm{HT}_{2 \mathrm{a}}$ or $5-\mathrm{HT}_{2 \mathrm{a} / 2 \mathrm{c}}$ antagonists, appear to be more effective in decreasing negative symptoms than haloperidol, (Kane et al. 1988; Meltzer 1992, 1997; Moller et al. 1995; Tollefson and Sanger 1996). Sertindole, risperidone, ziprasidone, M100907, and ritanserin have all been found effective in treating negative symptoms (Arvanitis and Miller 1997; Arato et al. submitted). Various types of analyses to partial out the effect on negative symptoms from the effect on positive and depressive symptoms and EPS suggest that the effect on negative symptoms is direct (Moller et al. 1995; Tollefson and Sanger 1996). These diverse compounds share relatively high $5-\mathrm{HT}_{2 \mathrm{a}}$ receptor blockade without $\mathrm{D}_{2}$ antagonism, whereas chlorpromazine and high dose loxapine, which produce high levels of $\mathrm{D}_{2}$ and $5-\mathrm{HT}_{2 \mathrm{a}}$ receptor blockade in vivo, do not improve negative symptoms. This suggests that $5-\mathrm{HT}_{2 \mathrm{a}}$ receptor blockade may play a key role in the treatment of negative symptoms only when $\mathrm{D}_{2}$ receptor blockade is absent or moderate. Efficacy to treat negative symptoms may be related to the ability of these agents to selectively increase dopaminergic activity in the prefrontal cortex since all these agents have been found to produce greater in- 
creases in DA release in the prefrontal cortex than the nucleus accumbens (Kuroki et al. 1999).

\section{5-HT ${ }_{2 \mathrm{~A}}$ RECEPTOR BLOCKADE AND COGNITIVE FUNCTION}

Clozapine, risperidone, and olanzapine have all been shown to improve selected areas of cognitive function in patients with schizophrenia, however, the available data suggests differential effects on specific functions. Most notably, clozapine appears to improve semantic memory, verbal learning and memory, and attention most reliably and robustly, whereas risperidone appears to improve working memory to the greatest extent (see Meltzer and McGurk in press for review). Olanzapine resembles clozapine more closely than risperidone (Purdon et al. 1998; Meltzer and McGurk in press). For example, in a study of 21 olanzapine treated patients, Purdon et al. (1998) reported improvement in some tests of attention, motor function, executive function and verbal memory at six weeks. Similar results were obtained by Meltzer and McGurk (in press) in a study of 29 patients treated with olanzapine for six weeks. Whether these effects are persistent and independent of improvement in psychopathology or lesser side effects is not yet known. There are, as yet, no data on the other drugs of this type. Whether $5-\mathrm{HT}_{2 \mathrm{a}}$ receptor antagonism has any role in the cognitive effects of these agents is not known. It may be that the effects of these agents on cognition depend mainly on their ability to increase the release of DA and acetylcholine in prefrontal cortex, which may depend, in part, on their serotonergic actions. Because cognitive enhancement is critical for functional improvement in schizophrenia, establishing the mechanism for this effect is of the greatest importance. The evidence concerning 5-HT receptors and cognition has recently been reviewed by Buhot (1997) and by Meneses and Hong (1997). The sparse literature on this topic mainly involves lower animals; the data suggest that $5-\mathrm{HT}_{2 \mathrm{a} / 2 \mathrm{c}}$ antagonists have little adverse effects and no apparent beneficial effects on learning and memory (Ruotsalainen et al. 1997).

Recent studies suggest that the novel antipsychotic drugs may enhance cholinergic function in the prefrontal cortex (Parada et al. 1997), and this may mediate their ability to improve cognition. Interactions between the 5-HT and cholinergic systems have been previously reported (Altman et al. 1987). Also, impairment of working memory in man following administration of the $5-\mathrm{HT}_{1 \mathrm{a}}$ agonist, flesinoxan, has been reported (Herremans et al. 1995).

It has recently been demonstrated that stimulation of $5-\mathrm{HT}_{2 \mathrm{a}}$ receptors by DOI increases the expression of brain-derived neurotrophic factor (BDNF), which regulates the survival, differentiation, synaptic strength, and neuronal morphology in the cerebral cortex and hippocampus, in frontal and other cortical areas while decreasing its expression in the dentate gyrus granule cell layer (Vaidya et al. 1997). This effect was blocked by M100907 which did not by itself have any effect in these regions. Stress had the same effect as DOI in increasing hippocampal BDNF levels. This was blocked by pretreatment with ketanserin, a $5-\mathrm{HT}_{2 \mathrm{a}}$ antagonist. These data suggest that the atypical antipsychotic drugs, via their $5-\mathrm{HT}_{2 \mathrm{a}}$ antagonism, might prevent the deleterious effects of stress on hippocampal cognitive measures. Increased corticosteroids may be neurotoxic (Sapolsky 1994). We have previously shown that clozapine decreases elevated plasma cortisol levels in schizophrenic patients, returning them to normal levels (Meltzer et al. 1989). This may be related to the ability of clozapine to improve cognitive function as well.

\section{5-HT ${ }_{2 \mathrm{~A}}$ RECEPTOR BLOCKADE AND EXTRAPYRAMIDAL FUNCTION}

Several lines of evidence suggest that potent $5-\mathrm{HT}_{2 \mathrm{a}}$ receptor blockade is related to the low EPS profile of clozapine but that 5- $\mathrm{HT}_{2 \mathrm{a}}$ receptor blockade by itself cannot explain the low EPS liability of these agents. Altar et al. (1986) and Rasmussen and Aghajanian (1988) suggested that weak $\mathrm{D}_{2}$ and potent $5-\mathrm{HT}_{2 \mathrm{a}}$ receptor blockade was the basis for the ability of clozapine to cause low extrapyramidal side effects. However, other explanations for the low EPS of clozapine have been offered-namely its anticholinergic properties, lack of ability to increase acetylcholine in the striatum, $\mathrm{D}_{1}$ and $\mathrm{D}_{4}$ receptor blockade, and its effects as an $\alpha_{2}$-adrenoceptor antagonist (Meltzer and Fatemi 1996; Parada et al. 1997; Kalkman et al. 1998).

In order to test the role of $5-\mathrm{HT}_{2 \mathrm{a}}$ receptor blockade, Meltzer et al. (1989) studied a group of compounds which had antipsychotic activity in man or in animal models and which produced less EPS in man or weak catalepsy in animals. Among the drugs studied was melperone, a butyrophenone long used in Europe and Scandinavia as an antipsychotic and reported to produce low EPS (Meltzer et al. 1994). This drug has recently been found to be tolerable to patients with Parkinson's Disease (Barbato et al. 1996), even more so than risperidone andolanzapine. The drugs reportedly shared weak $\mathrm{D}_{2}$ and potent $5-\mathrm{HT}_{2 \mathrm{a}}$ receptor affinities, whereas $D_{1}$ receptor affinities did not contribute to their effect. Subsequently, numerous compounds of diverse chemical structure which share this pharmacologic profile have been deliberately synthesized and tested for antipsychotic action and EPS potential. They include risperidone, olanzapine, sertindole, quetiapine, ziprasidone, and olanzapine. In development are iloperidone, M100907, and SR43649B; the latter is virtually devoid of 
any $\mathrm{D}_{2}$ affinity, and highly selective for the $5-\mathrm{HT}_{2 \mathrm{a}}$ receptors. All of these compounds produce fewer EPS than haloperidol at comparable doses, but there are differences between them. The dose response curve, together with PET studies of DA receptor occupancy strongly suggest that keeping $5-\mathrm{HT}_{2 \mathrm{a}}$ receptor high relative to $D_{2}$ receptor occupancy is necessary to avoid EPS with these compounds. There are preclinical data to support this. Ishikane et al. (1997) reported that M 100907 is able to block haloperidol-induced catalepsy only at low doses of haloperidol. Similarly, Spampinato et al. (1998) reported that specific 5- $\mathrm{HT}_{2 \mathrm{a}}$ and $5-\mathrm{HT}_{2 \mathrm{c}}$ antagonists were able to modulate the ability of haloperidol $0.01 \mathrm{mg} / \mathrm{kg}$, but not $1.0 \mathrm{mg} / \mathrm{kg}$ to increase striatal DA release in freely moving rats. It should be noted that Pilowsky et al. (1997b) found high $\mathrm{D}_{2}$ receptor occupancy in the basal ganglia in sertindole-treated patients, despite low EPS. This would indicate that some feature of the drugs, perhaps high $5-\mathrm{HT}_{2 \mathrm{a}}$ receptor occupancy, but conceivably other aspects of its pharmacology as well, might contribute to the low EPS and overcome the effects of a high degree of $\mathrm{D}_{2}$ receptor blockade. It should be noted that the relative affinities for $5-\mathrm{HT}_{2 \mathrm{a}}$ and $D_{2}$ receptors does not appear to be relevant to the ability of antipsychotics to induce dystonias in Cebus monkeys (Casey 1993). However, the relevance of these data to human EPS may be limited. For example, as noted above, melperone is well tolerated in patients with Parkinson's disease and L-DOPA psychosis who are exquisitely sensitive to drugs which cause EPS (Meltzer et al. 1989) but it produces dystonia in monkeys (Casey 1991).

\section{THE ROLE OF THE 5-HT ${ }_{2 \mathrm{C}}$ RECEPTOR IN ANTIPSYCHOTIC DRUG ACTION: 5- $\mathrm{HT}_{2 \mathrm{~A}}$ AND 5-HT ${ }_{2 \mathrm{C}}$ INTERACTIONS}

No significant differences have been reported between novel antipsychotic drugs and typical neuroleptics with regard to the affinity for $5-\mathrm{HT}_{2 \mathrm{c}}$ receptor or the difference between 5- $\mathrm{HT}_{2 \mathrm{c}}$ and $\mathrm{D}_{2}$ affinities (Roth et al. 1992, 1994; Schotte et al. 1996). Of the approved novel antipsychotic drugs, some have equivalent affinities for the $5-\mathrm{HT}_{2 \mathrm{a}}$ and $5-\mathrm{HT}_{2 \mathrm{c}}$ receptors (clozapine, olanzapine, sertindole), while others are more selective for the $5-\mathrm{HT}_{2 \mathrm{a}}$ receptor (risperidone, quetiapine, ziprasidone). This difference roughly corresponds to the potential to produce weight gain in that clozapine and olanzapine cause the greatest weight gain, and risperidone and ziprasidone the least. There is little available data for sertindole and quetiapine but they appear to be intermediate.

There is no apparent relationship between $5-\mathrm{HT}_{2 \mathrm{c}}$ affinity and $5-\mathrm{HT}_{2 \mathrm{a}}$ affinity with regard to EPS, since quetiapine and ziprasidone are comparable to olanzapine and sertindole in this regard. Similarly, there is no ap- parent relationship to efficacy in treatment-resistant schizophrenia. There could be a relationship to cognitive function since olanzapine and clozapine are similar to each other and differ from risperidone, but further studies are needed to determine the cognitive effects of all these agents before firm conclusions can be drawn (Meltzer and McGurk in press). 5- $\mathrm{HT}_{2 \mathrm{c}}$ receptor stimulation by the selective 5- $\mathrm{HT}_{2 \mathrm{c}}$ agonist Ro 60-0175 has been reported to markedly suppress dialysate levels of dDAn and noradrenaline in the frontal cortex of awake freely moving rats whereas the selective $5-\mathrm{HT}_{2 \mathrm{c}}$ antagonist, SB-242084, had the opposite effect (Millan et al. 1998). Thus, the 5- $\mathrm{HT}_{2 \mathrm{c}}$ antagonist effects of some of the atypical antipsychotic drugs may contribute to their ability to increase dopaminergic activity in the prefrontal cortex.

An interesting aspect of the 5- $\mathrm{HT}_{2 \mathrm{c}}$ receptor with regard to antipsychotic action is that 5- $\mathrm{HT}_{2 \mathrm{c}}$ antagonism may be functionally opposed to $5-\mathrm{HT}_{2 \mathrm{a}}$ antagonism. Meltzer et al. (1996) reported that atypical antipsychotic drugs were more likely to be weak $5-\mathrm{HT}_{2 \mathrm{c}}$ and potent $5-\mathrm{HT}_{2 \mathrm{a}}$ antagonists than to typical neuroleptic drugs. Neurochemical (Spampinato et al. 1997, 1998) and behavioral (Martin et al. 1997) data have now been reported supporting the notion of a functional antagonism of these two receptors which may coexist on the same neurons. Thus, Martin et al. (1997) found that ritanserin, a mixed 5- $\mathrm{HT}_{2 \mathrm{a} / 2 \mathrm{c}}$ antagonist, blocked the ability of M100907 to antagonize the effect of MK-801 in increasing locomotor activity in mice.

\section{THE ROLE OF THE 5-HT ${ }_{1 \mathrm{~A}}$ RECEPTOR IN ANTIPSYCHOTIC DRUG ACTION: 5-HT ${ }_{1 \mathrm{~A}}$ AND 5 -HT ${ }_{2 \mathrm{~A}}$ INTERACTIONS}

Although there is limited clinical data to support the role of the $5-\mathrm{HT}_{1 \mathrm{a}}$ receptor in the action of antipsychotic drugs, there is increasing amounts of preclinical evidence that it is of considerable importance. The $5-\mathrm{HT}_{1 \mathrm{a}}$ receptor is located pre- and postsynaptically. The presynaptic $5-\mathrm{HT}_{1 \mathrm{a}}$ receptor is an autoreceptor located on cell bodies of raphe neurons; stimulation leads to inhibition of the firing of 5-HT neurons. Stimulation of postsynaptic $5-\mathrm{HT}_{1 \mathrm{a}}$ receptors leads to hyperpolarization of neurons - the opposite effect of stimulation of 5- $\mathrm{HT}_{2 \mathrm{a}}$ receptors.

Extensive evidence indicates that $5-\mathrm{HT}_{1 \mathrm{a}}$ receptor agonists have effects similar to $5-\mathrm{HT}_{2 \mathrm{a}}$ receptor antagonists in a variety of systems (Darmani et al. 1990; Meltzer and Maes 1995). A few examples will be given. DOI injected bilaterally into the rat medial prefrontal cortex elicited a dose-dependent head twitch response. This effect wa inhibited by M100907 and ketanserin, but the selective 5- $\mathrm{HT}_{2 \mathrm{c}}$ antagonist SDZ SER082. Pretreatment with the $5-\mathrm{HT}_{1 \mathrm{a}}$ agonist 8-OH-DPAT inhibited the head 
twitch response to DOI. Ahlenius (1988) first suggested that stimulation of $5-\mathrm{HT}_{1 \mathrm{a}}$ receptors might produce an antipsychotic-like effect, based on behavioral studies in animals using the direct $5-\mathrm{HT}_{1 \mathrm{a}}$ agonist 8-OH-DPAT.

Subsequent studies demonstrated that 8-OH-DPAT enhanced the antipsychotic-like effect of the $D_{2} / D_{3}$ antagonist raclopride (Wadenberg and Ahlenius 1991) and of haloperidol (Prinssen et al. 1996), and antagonized the catalepsy induced by the $\mathrm{D}_{1}$ agonist $\mathrm{SCH} 23390$ in rats (Wadenberg 1992). The beneficial effect of 5- $\mathrm{HT}_{1 \mathrm{a}}$ agonists appears to be mediated by inhibition of median raphe serotonergic neurons (Wadenberg and Hillegaart 1995). Ichikawa and Meltzer (1995) demonstrated that 8-OH-DPAT inhibited the ability of clozapine and low dose risperidone but not haloperidol to increase extracellular DA levels in the nucleus accumbens and the striatum of conscious rats. The effect in the nucleus accumbens would be expected to enhance the antipsychotic effect of these agents by reducing dopaminergic activity. Several atypical antipsychotic drugs, including clozapine, ziprasidone, quetiapine, and tiospirone, are partial agonists at the $5-\mathrm{HT}_{1 \mathrm{a}}$ receptor. Their affinities for the $5-\mathrm{HT}_{1 \mathrm{a}}$ receptor were similar to their affinities at the human $\mathrm{D}_{2}$ dopamine receptor (Newman-Tancredi et al. 1998). Rollema et al (1997) demonstrated that the ability of clozapine to increase DA release in the rat prefrontal cortex was due to its $5-\mathrm{HT}_{\mathrm{a}}$ agonist properties, in that it could be blocked by WAY-100635, a 5- $\mathrm{HT}_{1 \mathrm{a}}$ antagonist. These findings suggest that the combination of $\mathrm{D}_{2}$ antagonism and $5-\mathrm{HT}_{1 \mathrm{a}}$ agonism should produce an atypical antipsychotic agent. S16924 is an example of such a compound and it has atypical properties very similar to those of clozapine in a variety of animal models (Millan et al. 1998a, 1998b). How closely such compounds will parallel $5-\mathrm{HT}_{1 \mathrm{a}} / \mathrm{D}_{2}$ antagonists remains to be determined. Significant differences should be expected. Compounds such as ziprasidone and clozapine combine 5- $\mathrm{HT}_{1 \mathrm{a}}$ agonism and 5- $\mathrm{HT}_{2 \mathrm{a}}$ antagonism.

Clinical studies of adding $5-\mathrm{HT}_{1 \mathrm{a}}$ partial agonists such as buspirone, ipsapirone, and tandospirone may help to clarify the possible importance of $5-\mathrm{HT}_{1 \mathrm{a}}$ agonism in the treatment of schizophrenia. It seems likely that there could be a new generation of antipsychotic drugs that incorporate $5-\mathrm{HT}_{1 \mathrm{a}}$ agonism.

\section{THE ROLE OF SEROTONIN RELEASE IN ANTIPSYCHOTIC DRUG ACTION}

The antagonism of multiple 5-HT receptors by clozapine would be expected to enhance the release of 5-HT by feedback mechanisms. Thus, it was surprising that Ferré and Artigas (1995) reported that clozapine decreased 5-HT release in the nucleus accumbens. However, Ichikawa et al. (1998) reported that clozapine (20 $\mathrm{mg} / \mathrm{kg})$ and risperidone $(1 \mathrm{mg} / \mathrm{kg})$ significantly in- creased extracellular 5-HT levels in the nucleus accumbens and medial prefrontal cortex, respectively, whereas amperozide (1 and $10 \mathrm{mg} / \mathrm{kg}$ ) increased extracellular 5-HT levels in both regions. Hertel et al. (1997) reported similar results with risperidone and suggested that they might be releated to its ability to improve negative symptoms. If so, this is not the explanation for the effects of clozapine or olanzapine on negative symptoms since olanzapine, sulpiride, haloperidol, and M100907 had no effect on extracellular 5-HT levels in either region. The latter finding indicates that blockade of 5- $\mathrm{HT}_{2 \mathrm{a}}$ receptors is not the basis for the ability of clozapine, risperidone or amperozide to increase $5-\mathrm{HT}_{2 \mathrm{a}}$ levels (Ichikawa et al. 1998). The enhancement of 5-HT efflux in the prefrontal cortex may contribute to the ability of these agents to improve mood disorders and cognition.

\section{CONCLUSIONS}

There is strong evidence for the role of $5-\mathrm{HT}_{2 \mathrm{a}}$ receptors and suggestive evidence for the roles of the $5-\mathrm{HT}_{1 \mathrm{a}}$ and $5-\mathrm{HT}_{2 \mathrm{c}}$ receptors in the antipsychotic effects and ability to improve cognition of arious actions of clozapine, risperidone, olanzapine, quetiapine, ziprasidone, iloperidone, sertindole, and related antipsychotic drugs. Studies of specific antagonists and agonists of these receptors, alone and together with $\mathrm{D}_{2}$ receptor antagonists and dopaminomimetic agents such as L-DOPA, amphetamine, and others will help to clarify their importance. Thus, if selective $5-\mathrm{HT}_{2 \mathrm{a}}$ antagonists such as M100907 and SR 46439B are effective in the treatment of auditory hallucinations or paranoid delusions induced by pharmacologically enhanced dopamine activity, the case for the importance of $5-\mathrm{HT}_{2 \mathrm{a}}$ receptor blockade in the treatment of psychosis will be supported. There is considerable evidence that $5-\mathrm{HT}_{2 \mathrm{a}}$ receptor antagonism is most usefully conceptualized in relation to dopamine receptor antagonism. $\mathrm{D}_{2}$ receptors appears to be the most important in this regard but it is likely that the $D_{1}$, $D_{3}$, and $D_{4}$ receptors will also influence various components of psychosis, mood, motivation, and cognition that are relevant to the clinical applications of the atypical antipsychotic drugs.

Potent 5- $\mathrm{HT}_{1 \mathrm{a}}$ agonism, and possibly 5- $\mathrm{HT}_{2 \mathrm{c}}$ receptor agonism and $5-\mathrm{HT}_{6}$ or $5-\mathrm{HT}_{7}$ receptor antagonism may also be the basis for some of the actions of the current generation of atypical antipsychotic drugs and the basis for developing novel agents that do not necessarily have to be 5- $\mathrm{HT}_{2 \mathrm{a}}$ antagonists. Multi-receptor agents appear to be more promising as antipsychotic agents for the majority of psychiatric patients because of important interactions between neural circuits which employ multiple neurotransmitters. Underlying the efficacy of antipsychotic drugs which affect the serotonergic system is probably abnormalities in the serotonergic system 
itself, e.g., increased $5-\mathrm{HT}_{2 \mathrm{a}}$ and possibly decreased $5-\mathrm{HT}_{1 \mathrm{a}}$ receptor stimulation. However, the case of Parkinson's psychosis induced by L-DOPA or bromocriptine suggests that drugs such as clozapine and melperone may be effective antipsychotics via their $5-\mathrm{HT}_{2 \mathrm{a}}$ receptor antagonist properties even when the primary abnormality is mainly excessive dopaminergic stimulation.

The limitations in the scope of this review to some of the literature on serotonin and dopamine with regard to the action of the new antipsychotic drugs necessitated omitting attention to the importance of other neurotransmitters such as acetylcholine, glutamate and norepinephrine. These neurotransmitters most certainly contribute to the morbid state in psychosis and are influenced by the newer agents directly or indirectly. Despite the importance of these other neurotransmitters, only the antipsychotic drugs which have a spectrum of effects on the serotonergic system, particularly the 5-HT2a receptor, have produced highly relevant advances in the treatment of psychosis. There are no antipsychotic drugs yet available which have primary effects on any of these other neurotransmitters. This provides supports for a continued focus on serotonin, and especially serotonin-dopamine interactions, with regard to antipsychotic drug actions.

\section{ACKNOWLEDGMENTS}

This study was supported, in part, by grants from the Essel, Lattner, and Warren Foundations.

\section{REFERENCES}

Abi-Dargham A, Laruelle M, Aghajanian GK (1997): The role of serotonin in the pathophysiology and treatment of schizophrenia. J Neuropsy Clin Neurosci 9:1-17

Ahlenius S (1988): Antipsychotic-like properties of the $5-\mathrm{HT}_{1 \mathrm{a}}$ agonist 8-OH-DPAT in the rat. Pharmacol Toxicol 64:3-5

Altman HJ, Stone WS, Ögren S (1987): Evidence for a possible functional interaction between serotonergic and cholinergic mechanism in memory retrieval. Behav Neural Biol 48:49-62

Altar CA, Wasley AM, Neale RF, Stone GA (1986): Typical and atypical antipsychotic occupancy of $\mathrm{D}_{2}$ and $\mathrm{S}_{2}$ receptors: An autoradiographic analysis in rat brain. Brain Res Bull 16:517-525

Arndt J, Skarsfeldt T (1998): Do novel antipsychotics have similar pharmacological characteristics? A review of the evidence. Neuropsychopharmacology 18:63-101

Arvanitis LA, Miller BG (1997): Multiple fixed dose of "Sero-

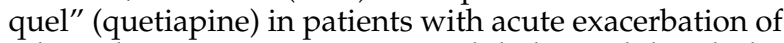
schizophrenia: A comparison with haloperidol and placebo. The Seroquel Trial 13 Study Group. Biol Psychiatry 42:233-246
Barbato L, Monge A, Stocchi F, Nordera G (1996): Melperone in the treatment of iatrogenic psychosis in Parkinson's Disease. Clin Neuropharmacol 11:201-207

Bondolfi G, Dufour H, Patris M, May JP, Billeter U, Eap CB, Baumann P (1998): Risperidone versus clozapine in treatment resistant chronic schizophrenia: A randomized double-blind study. The Risperidone Study Group. Am J Psychiatry 155:499-504

Buhot M-C (1997): Serotonin receptors in cognitive behaviors. Curr Opin Neurobiol 7:243-254

Calabrese J, Kimmel SE, Woyshiville M, Rapport WJ, Trivedi CJ, Meltzer HY (1996): Clozapine in treatment refractory mania. Am J Psychiatry 153:759-764

Casey DE (1991): Extrapyramidal syndromes in nonhuman primates: Typical and atypical neuroleptics. Psychopharmacol Bull 27:47-50

Casey DE (1993): Serotonergic and dopaminergic aspects of neuroleptic-induced extrapyramidal syndromes in nonhuman primates. Psychopharmacology 112(Suppl 1): S55-S59

Conley RR, Tamminga CA, Bartko JJ, Richardson C, Peszke M, Lingle J, Hegerty J, Love R, Counaris C, Zaremba S (1998a): Olanzapine compared with chlorpromazine in treatment-resistant schizophrenia. Am J Psychiatry 155:914-920

Conley RR, Kelly DL, Gale EA (1998b): Olanzapine response in treatment-refractory schizophrenic patients with a history of substance abuse. Schiz Res 33:95-101

Darmani NA, Martin BR , Pandy U, Glennon RA (1990): Do functional relationships exist between $5-\mathrm{HT}_{1 \mathrm{a}}$ and $5-\mathrm{HT}_{2}$ receptors? Pharmacol Biochem Behav 26:901-906

Deutch AY, Duman RS (1996): The effects of antipsychotic drugs on fos protein expression in the prefrontal cortex: Cellular localization and pharmacological characterization. Neuroscience 70:377-389

Ferré S, Artigas F (1995): Clozapine decreased serotonin extracellular levels in the nucleus accumbens by a dopamine receptor-independent mechanism. Neurosci Lett 187:61-64

Fiorella D, Helsley S, Rabin RA, Winter JC (1995): The interactions of typical and atypical antipsychotics with the (-)2,5-dimethoxy-4-methamphetamine (DOM) discriminative stimulus. Neuropharmacology 34:1297-303

Ganguli R, Brar JS (1998): The effects of risperidone and olanzapine on the indications for clozapine. Psychopharmacol Bull 34(1):83-87

Gleason SC, Shannon HE (1997): Blockade of phencyclidineinduced hyperlocomotion by olanzapine, clozapine and serotonin receptor subtype selective antagonists in mice. Psychopharmacology 129:79-84

Guo N, Klitenick MA, Tham CS, Fibiger HC (1995): Receptor mechanism mediating clozapine-induced $c$-fos expression in the forebrain. Neuroscience 65:747-756

Herremans AH, Hijzen TH, Olivier B, Slangen JL (1995): Serotonergic drug effects on a delayed conditional task in the rat: Involvement of the $5-\mathrm{HT}_{1 \mathrm{a}}$ receptor in working memory. J Psychopharmacol 9:242-250

Hertel P, Nomikos G, Schilstrom B, Arborelius L, Svensson TH (1997): Risperidone dose-dependently increases extracellular concentrations of serotonin in the rat fron- 
tal cortex: Role of $\alpha_{2}$ - adrenoceptor antagonism. Neuropsychopharmacology 17:44-55

Ichikawa J, Kuroki T, Dai J, Meltzer, HY (1998): Effect of antipsychotic drugs on extracellular serotonin levels in rat medial prefrontal cortex and nucleus accumbens. Eur J Pharmacol 351:163-171

Ichikawa J, Kuroki T, Kitchen MT, Meltzer HY (1995): R(+)8-OH-DPAT, a 5- $\mathrm{HT}_{1 \mathrm{a}}$ receptor agonist, inhibits amphetamine-induced serotonin and dopamine release in rat striatum and nucleus accumbens. Eur J Pharmacol 287:179-184

Ichikawa J, Meltzer HY (1995): DOI, a 5- $\mathrm{HT}_{2 \mathrm{a} / 2 \mathrm{c}}$ receptor agonist, potentiates amphetamine-induced dopamine release in rat striatum. Brain Res 698:204-208

Ishikane T, Kusumi I, Matsubara R, Matsubara S, Koyama T (1997): Effects of serotonergic agents on the up-regulation of dopamine D2 receptors induced by haloperidol in rat striatum. Eur J Pharmacol 321:163-169

Jakab RL, Goldman-Rakic P (1998): 5-Hydroxytryptamine 2a serotonin receptors in the primate cerebral cortex: Possible site of action of hallucinogenic and antipsychotic drugs in pyramidal cell apical dendrites. Proc Natl Acad Sci USA 95:735-740

Kalkman HO, Neumann V, Hoyer D, Tricklebank MD (1998): The role of $a_{2}$-adrenoceptor antagonism in the anti-cataleptic properties of the atypical neuroleptic agent, clozapine, in the rat. Br J Pharmacol 124:1550 1556

Kane J, Honigfeld G, Singer J, Meltzer HY and the Clozaril Collaborative Study Group (1988): Clozapine for the treatment-resistant schizophrenic. Arch Gen Psychiatry 45:789-796

Kapur S, Remington G (1996): Serotonin-dopamine interaction and its relevance to schizophrenia. Am J Psychiatry 153:466-476

Kinon BJ, Lieberman JA (1996): Mechanisms of action of atypical antipsychotic drugs-A critical analysis [review]. Psychopharmacology 124:2-34

Kuroki T, Meltzer HY, Ichikawa J (1999): Effects of antipsychotic drugs on extracellular dopamine levels in rat medial prefrontal cortex and nucleus accumbens. J Pharmacol Exp Ther 288:774-781

Leslie RA, Moorman JM, Coulson A, Grahame-Smith DG (1993): Serotonin $_{2 / 1 C}$ receptor activation causes a localized expression of the immediate-early gene c-fos in rat brain: Evidence for involvement of dorsal raphe nucleus projection fibres. Neuroscience 53:457-463

Maes M, Meltzer HY (1995): Chapter 81. The serotonin hypothesis of depression. In Nemeroff CB, Kupfer D (eds), Psychopharmacology: The Fourth Generation of Progress. New York, NY, Raven Press, pp 933-944

Marder SR, Meibach RC (1994): Risperidone in the treatment of schizophrenia. Am J Psychiatry 151:825-835

Martin P, Water N, Carlsson A, Carlsson ML (1997): The apparent antipsychotic action of the $5-\mathrm{HT}_{2 \mathrm{a}}$ receptor antagonist M100907 in a mouse model of schizophrenia is counteracted by ritanserin. J Neural Transm 104:561-564

Masellis FM, Macciardi FM, Meltzer HY, Lieberman JA, Sevy S, Cavazzoni P, Cola P, Howard A, Badri F, Nothen M, Kalow W, Kennedy JL (1998): Serotonin subtype 2 receptor genese and clinical response to clozapine in schizophrenic patients. Neuropsychopharmacology 19:123-132

Meltzer HY (1979): The clozapine story. In Hertzman M, Feltner DE (eds), The Handbook of Psychopharmacology Trials. New York, NY, New York University Press, pp 137-156

Meltzer HY (1992): Treatment of the neuroleptic non-responsive schizophrenic patient. Schiz Bull 18:515-542

Meltzer HY (1997): Treatment-resistant schizophrenia-The role of clozapine. Curr Med Res Op 14:1-20

Meltzer HY, Fatemi SH (1996): The role of serotonin in schizophrenia and the mechanism of action on anti-psychotic drugs. In Kane JM, Moller HJ, Awouters F (eds), Serotonergic Mechanisms in Antipsychotic Treatment. New York, NY, Marcel Decker, pp 77-107

Meltzer HY, Kennedy J, Dai J, Parsa M, Riley D (1995): Plasma clozapine levels and the treatment of L-DOPAinduced psychosis in Parkinson's disease: A high potency effect of clozapine. Neuropsychopharmacology 12:39-45

Meltzer HY, Lee MA, Ranjan R, Mason ED, Cola PA (1996a): Relapse following clozapine withdrawal: Effect of cyproheptadine plus neuroleptic. Psychopharmacology 124:176-187

Meltzer HY, Maes M (1995): Pindolol pretreatment blocks stimulation by metachlorophenylpiperazine of prolactin but not cortisol secretion in normal men. Psychiatry Res 58:89-98

Meltzer HY, Matsubara S, Lee J-C (1989): Classification of typical and atypical antipsychotic drugs on the basis of dopamine D-1, D-2 and serotonin2 pKi values. J Pharmacol Exp Ther 251:238-246

Meltzer HY, McGurk SR (in press): The effect of clozapine, risperidone and olanzapine on cognitive function in schizophrenia. Schiz Bull

Meltzer HY, Nash JF (1991): Effects of antipsychotic drugs on serotonin receptors. Pharmacol Rev 43:587-604

Meltzer HY, Okayli G (1995): The reduction of suicidality during clozapine treatment in neuroleptic-resistant schizophrenia: Impact on risk-benefit assessment. Am J Psychiatry 152:183-190

Meltzer HY, Roth B, Thompson P (1996b): Serotonin and dopamine receptor affinites predict atypical antipsychotic drug (AAD) activity. Neurosci Abstr 22:480

Meneses A, Hong E (1997): A pharmacological analysis of serotonergic receptors: Effect of their activation of blockade in learning. Prog Neuropsychopharmacol Biol Psychiatry 21:273-296

Millan MJ, Dekeyne A, Gobert A (1998a): Serotonin (5-HT) 2 c receptors inhibit dopamine (DA) and noradrenaline (NA), but not 5-HT, release in the frontal cortex in vivo. Neuropharmacology 27:953-955

Millan MJ, Gobert A, Newman-Tancredi A, Audinot V, Lejeune F, Rivet J-M, Cussac D, Nicolas J-P, Muller O, Lavielle G (1998b): S16924 ((R)-2-\{1-[2-(2,3-dihydrobenzo[1,4] dioxin-5-yloxy)-ethyl]-pyrrolidin-3yl\}-1-(4fluoro-phenyl)-ethanone), a novel potential antipsychotic with marked serotonin $5-\mathrm{HT}_{1 \mathrm{~A}}$ agonist properties. 1 . Receptorial and neurochemical profile in comparison with clozapine and haloperidol. J Pharmacol Exp Ther 286:1341-1355 
Moller HJ, Muller H, Borison RL, Schooler NR, Chouinard G (1995): A path-analytical approach to differentiate between direct and indirect drug effects on negative symptoms in schizophrenic patients. A re-evaluation of the North American risperidone study. Euro Arch Psychiatry Clin Neurol 245:45-49

Mountjoy CQ, Baldacchino AM, Stubbs JH (1998): British experience with high-dose olanzapine for treatmentrefractory schizophrenia. Am J Psychiatry 156:158-159

Newman-Tancredi A, Gavaudan S, Conte C, Chaput C, Touzard M, Verrièle L, Audinot V, Millan MJ (1998): Agonist and antagonist actions of antipsychotic agents at $5-\mathrm{HT}_{1 \mathrm{a}}$ receptors: A [ $\left.{ }^{35} \mathrm{~S}\right] \mathrm{GTP} \gamma \mathrm{S}$. Eur J Pharmacol 355:245-256

Parada MA, Hernandez L, Puig de Parada M, Rada P, Murzi E (1997): Selection action of acute systemic clozapine on acetylcholin release in the rat prefrontal cortex by reference to the nucleus accumbens and striatum. J Pharmacol Exp Ther 281:582-588

Pilowsky LS, Mulligan RS, Acton PD, Ell PJ, Costa DC, Kerwin RW (1997a): Limbic selectivity of clozapine. Lancet 350:490-491

Pilowsky LS, O'Connell PO, Davies N, Busatto GH, Costa DA, Murray RM, Ell PJ, Kerwin RW (1997b): In vivo effects on striatal dopamine $\mathrm{D}_{2}$ receptor binding by the novel atypical antipsychotic drug sertindole-A ${ }^{223} \mathrm{I}$ IBZM single photon emission tomography (SPET) study. Psychopharmacology 130:152-158

Prinssen EPM, Kleven MS, Koek W (1996): Effects of dopamine antagonists in a two-way active avoidance procedure in rats: Interactions with 8-OH-DPAT, ritanserin, and prazosin. Psychopharmacology 128:191-197

Protais P, Chagraoui A, Arbaoui J (1994): Dopamine receptor antagonist properties of S 14506, 8-OH-DPAT, raclopride and clozapine in rodent. Eur J Pharmacol 271:167173

Purdon SE, Jones BDW, Stip E, Labelle A, Addington D, Breier A, Tollefson D and the Canadian Collaborative Group for Research on Cognition in Schizophrenia (1998): Olanzapine vs. risperidone and haloperidol in the treatment of cognitive impairment in schizophrenia. Presented at the American College of Neuropsychopharmacology Annual Meeting. Las Croabas, Puerto Rico, December 14-18, 1998

Rasmussen K, Aghajanian GK (1988): Potency of antipsychotics in reversing the effects of a hallucinogenic drug on locus coeruleus neurons correlates with $5-\mathrm{HT}_{2}$ binding affinity. Neuropsychopharmacology 1:101-107

Rinaldi-Carmona M, Congy C, Santucci V, Simiand J, Gautret B, Neliat G, Labeeuw B, Le Fur G, Soubrié PG, Breliere JC (1992): Biochemical and pharmacological properties of SR 46349B, a new potent and selective 5-hydroxytryptamine ${ }_{2}$ receptor antagonists. J Pharmacol Exp Ther 262:759-768

Robertson GS, Matsumura H, Fibiger HC (1994): Induction patterns of fos-like immunoreactivity in the forebrain as predictors of atypical antipsychotic activity. J Pharmacol Exp Ther 271:1058-1066

Rollema H, Lu Y, Schmidt AW (1997): Clozapine increases dopamine release in prefrontal cortex by $5-\mathrm{HT}_{1 \mathrm{a}}$ receptor activation. Eur J Pharmacol 338:R3-R5

Roth BL, Ciaranello RD, Meltzer HY (1992): Binding of typical and atypical antipsychotic agents with transiently expressed 5- $\mathrm{HT}_{1 \mathrm{c}}$ receptors. J Pharmacol Exp Ther 260:1361-1365

Roth B, Craigo SC, Choudhary MS, Ulue A, Monsma FJ, Shen Y, Meltzer HY, Sibley DR (1994): Binding of typical and atypical antipsychotic agents to 5-hydroxytryptamine-6 and 5-hydroxytryptamine-7 receptors. J Pharmacol Exp Ther 268:1401-1410

Ruotsalainen S, Sirvio J, Jäkälä P, Puumala T, MacDonald E, Riekkin P Sr (1997): Differential effect of three 5-HT receptor antagonists on the performance of rats in attentional and working memory tasks. Eur J Neuropsychopharmacol 7:99-108

Sapolsky RM (1994): The physiological relevance of glucocorticoid endangerment of the hippocampus. Ann NY Acad Sci USA 746:294-304

Schmidt CJ, Sorensen SM, Kehne JH, Carr AA, Palfreyman MG (1995): The role of 5- $\mathrm{HT}_{2 \mathrm{a}}$ receptors in antipsychotic activity. Life Sci 56:2209-2222

Schotte A, Janssen PFM, Gommeren W, Luyten WHML, Van Gompel P, Lesage AS, De Loore K, Leysen JE (1996): Risperidone compared with new and reference antipsychotic drugs: In vitro and in vivo receptor binding. Psychopharmacology 124:57-73

Shipley J (1998): M100907 Phase IIB Trial. Presented at Hoechst Marion Roussel Conference on M100907. West Palm Beach Florida, April 1998

Spampinato U, De Deuwwaerdere P, Caccia S, Lucas G (1998): Opposite role of central $5-\mathrm{HT}_{2 \mathrm{a}}$ and $5-\mathrm{HT}_{2 \mathrm{c}}$ receptors subtypes in the control of haloperidol-induced release of dopamine in the rat striatum. Neurosci Abstr 24:48.4

Spampinato U, Stinus L, De Deuwwaerdere P (1997): Effect of dorsal raphe electrical stimulation on stratial and accumbal dopamine release in the rat: Role of $5-\mathrm{HT}_{2 \mathrm{a} / 2 \mathrm{c}}$ and 5- $\mathrm{HT}_{3}$ receptors. Neurosci Abstr 23:907.8

Tollefson GD, Sanger TM. (1996): Negative symptoms: A path analytic approach to a double-blind, placebo-and haloperidol-controlled clinical trial with olanzapine. Am J Psychiatry 154:466-474

Truffinet P, Tamminga CA, Fabre LF, Meltzer HY, Riviere ME, Papillon-Downey C (in press): A placebo controlled study of the $\mathrm{D}_{4} / 5-\mathrm{HT}_{2 \mathrm{a}}$ antagonist fananserin in the treatment of schizophrenia. Am J Psychiatry

Vaidya VA, Marek GJ, Aghajanian GK, Duman RS (1997): $5-\mathrm{HT}_{2 \mathrm{a}}$ receptor-mediated regulation of brain-derived neurotrophic factor mRNA in the hippocampus and the neocortex. J Neurosci 17:2785-2795

Varty GB, Higgins GA (1995): Reversal of a dizocilpineinduced disruption of prepulse inhibition of an acoustic startle response by the $5-\mathrm{HT}_{2}$ receptor antagonist ketanserin. Eur J Pharmacol 287:201-205

Wadenberg ML (1992): Antagonism by 8-OH-DPAT, but not ritanserin, of catalepsy induced by SCH 23390 in the rat. J Neural Trans 89:49-59

Wadenberg ML, Ahlenius S (1991): Antipsychotic-like profile of combined treatment with raclopride and 8-OH-DPAT in the rat: Enhancement of antipsychotic-like effects without catalepsy. J Neural Trans [Gen Sect] 83:43-53

Wadenberg ML, Hillegaart V (1995): Stimulation of median, but nor dorsal, raphe $5-\mathrm{HT}_{1 \mathrm{a}}$ autoreceptors by the local application of 8-OH-DPAT reverses raclopride-induced catalepsy in the rat. Neuropharmacology 34:495-499 